\title{
Corporate Governance Decisions in Accounting Business Field for Increasing Competitiveness: Romania, France and Europe Comparison
}

\author{
Sorin R. Berinde \\ Babes-Bolyai University \\ Mihail Kogalniceanu st. 1, 400174, Cluj-Napoca, Romania \\ E-mail.sorin.berinde@tbs.ubbcluj.ro \\ cross $^{\text {ref }}$ http://dx.doi.org/10.5755/j01.ee.29.3.17269
}

\begin{abstract}
Creating value for shareholders in terms of equity value growth significantly depends on the ability of corporate governance to make optimal decisions for the company's competitiveness. The article conducts a comparative study between Romania, France and the average recorded in the European Union regarding competitiveness in companies from the accounting business field for the timeframe 2008-2013. Competitiveness is measured as the average for the domesticowned companies and separately for the foreign-owned companies. Competitiveness assessment is based on asset related elements, processes and performance. The key success factors used for assessing competitiveness are investment rate, gross operating rate, turnover per person employed, share of personal cost in production and added value. The data are collected through the European Statistical System and processed by means of competitiveness analysis methods used in the literature. The findings show that the competitiveness of Romanian and French companies from the accounting business field is above the European Union average. The hypothesis according to which the foreign-owned companies are more competitive than domestic-owned companies is partially confirmed. The foreign owned companies are increasing their competitiveness by reducing labour cost and increasing productivity and added value. They invest far less than companies with local ownership.
\end{abstract}

Keywords: Accounting; Competitiveness; Corporate Governance; Financial Indicators; Financial Analysis.

\section{Introduction}

Competitiveness is a broad concept that can be viewed as macroeconomic from the perspective of a country, an activity sector, or a company. Most studies in the literature, both the oldest and the newest, focus on the macroeconomic approach of competitiveness (Ketels, 2016; Porter, 1990). At this level, there is a link between governance, investor protection, entrepreneurship and economic performance (Rachisan et al., 2017, Grosanu et al., 2015). From the macroeconomic perspective, competitiveness is considered in the literature as the ability of a company to design, build and sell products and services superior to those offered by the competition, (D’Cruz, 1992), and the ability to accumulate sustainable growth and profitability (Cetindamar \& Kilitcioglu, 2013).

The conceptual differentiation between the macroeconomic (social infrastructure, political institutions, macroeconomic policy) and the microeconomic approaches regarding the competitiveness within companies (business environment quality, clusters, and company sophistication) has been recently performed (Perez-Moreno et al., 2016; Delgado et al., 2012, Porter, 2011) and they are not numerous (Mendola \& Volo, 2017).

This study aims to fill in the gap in the literature as it focuses on the microeconomic approach of studying the competitiveness of companies from the accounting business field. At the company level, the corporate governance initiatives to increase competitiveness will be explained by aspects related to companies' sophistication.
There is a general agreement in the literature that sophisticated business practices increase the efficiency in the production of goods and services (Schwab \& Sala-iMartin, 2011). Based on this, the study intends to explain the impact of corporate governance decisions on the competitiveness of companies from the accounting business field. For this purpose, we use competitiveness outcome indicators related to Romania, France and Europe as general average.

Competitiveness is assessed based on the aspects related to assets, processes and performance (Ajitabh \& Momaya, 2004). These patterns are determined based on the accounting information provided by financial accounting reports prepared under specific regulations.

The study covers the comparison between Romania and France because the Romanian accounting system is related to the French one, starting from certain key considerations. The Romanian accounting system, originally adopted in the post-communist period in Romania (after 1989), was French inspired. The reasons for adopting the French accounting system in Romania in that period, a continental system, were the existence of similarities between the two countries regarding the legal code, related to written law more than the common law, the prevailing financing in both countries through banking systems more than capital market, and the experience of French specialists available to build the Romanian accounting system. Therefore, in both countries the accounting system was originally designed to provide information to public institutions rather than to investors 
(Deaconu \& Cuzdriorean, 2016). Subsequently, during the last 10 years, both accounting systems have undergone a transition in order to adopt the accounting principles specific to the Anglo-Saxon accounting system, according to which the accounting principles in accounting prevail over the fiscal ones and the accounting information primarily is intended to inform investors. For the objective assessment of the competitiveness dimension, the European average level was taken into account. A variable for foreign controlled companies is included because it appears that the predominance of foreign ownership is a pattern capable of conditioning competitiveness (Ketels; Bodnaruk et al., 2016; Schwab \& Sala-i-Martin, 2011).

The methods applied for assessing the level of competitiveness, starting with patterns related to assets, processes and performance, are the geometric mean (Huggins et al., 2005), the competitive profile matrix (CPM) (Fleisher \& Bensoussan, 2015; Capps \& Glissmeyer, 2012; Gordon, 1989) and the distance method (World Bank Group, 2016). For achieving a final conclusion we used the aggregation process commonly used in the literature for the competitiveness analysis (World Bank Group, 2016; Djankov et al., 2005).

The findings show that, in order to become competitive, in some cases the corporate governance adopts policies to reduce costs and increase the added value, while in other cases to increase investments to become competitive in the long run.

The article is structured in five parts. The second part, the literature review, presents the competitiveness approaches in literature and places the study within them, the third part presents the methodology of data collection to ensure the representativeness of the results and justifies the data processing model, the fourth part consists of the research results on competitiveness, and the fifth part presents conclusions regarding the decisions adopted by the corporate governance for the purpose of facilitating companies' competitiveness from the accounting business field in Romania, France and the European average.

\section{Literature Review}

The studies published in the literature attempt to measure the competitiveness generated by the companies' sophistication, starting from several factors related to two broad categories: assets/processes (which refer to investments, human resources, innovations, firm structure, technology, technological processes, managing relationships, flexibility and adaptability, firm culture) and performance (revealed by productivity, profitability, cost and value creation) (Snieska, 2015; Ajitabh \& Momaya, 2004; Shee, 2002).

\section{Competitiveness through Assets and Processes}

The renewal of assets and the technological upgrading through investment programs intend to support competitiveness and wealth creation, whether through investments in tangible or intangible assets (Marin et al., 2017; Bagur-Femenias et al., 2015; Zhang, 2014; Shee, 2002; Ross et al, 1996). To stay competitive it is necessary to correlate long term investments with short term return (Skilbeck \& Cruickshank, 1997).

The human resources and innovation are considered a part of the concentric circles model that is able to generate competitiveness (Diaz-Chao et al., 2016; Boland, 2014).The ability of corporate governance as part of human resources to use accounting information in general and the information provided by the managerial accounting in particular (Johnson, 1994) and create business strategies based on available knowledge and acquired experience (Bambarger, 1989) is a prerequisite to support competitiveness. Human resources can support competitiveness with the condition that one should not excessively prioritize a single initiative that supports change (Chaston \& Mangels, 1997). Ensuring a reasonable level of staff competences by attracting, retaining and training of personnel with vocations contributes to the competitive potential of small and medium businesses in Mexico (Patlan-Perez \&De Lara, 2012). Important in this view are the activity field, the ownership typology, the firm structure, the size, and age of the company. Competitiveness is also created by the IT staff, which, in addition to the competence, must have a solid technological process background and strong relationships with business management (Westerlund et al., 2017; Ross et al., 1996). Corporate governance can significantly improve the competitiveness of companies by managing relationships, building skills through training, supporting innovation, improving the business-government relationship and bringing an activity back home from an international location (Chuang \& Huang; Husain et al., 2016; Wu \& Chiu, 2015; Porter et al., 2013). Also, the ability to have continuity in business, to be flexible and adaptable, to provide future employment is landmark of company competitiveness (Kharub et al, 2017, Wayne Pace \& Stephan, 1996).

For large companies competitiveness depends on their ability to adapt their activity to the culture of the country in which they operate (Smith, 1995). Some countries have specialized in providing certain services, especially those of a financial, communication or business nature, which leads to maintaining a globally competitive environment in the economy for that particular geographical area called cluster. Thus, it is more likely to increase the competitiveness of the companies from that sector (Ketels, 2016; Guerrieri \& Meliciani, 2005; Hardwick \& Dou, 1998). Therefore, the competitiveness of companies can be measured based on the degree of specialization of the economies in which they operate.

\section{Competitiveness through Performance}

The quality of management decisions, seen in the light of the company indicators' performance is one of the additional factors taken into consideration when quantifying the competitiveness framework. This approach is able to highlight the final outputs of corporate governance decisions (Ketels, 2016). Performance as a competitiveness indicator can be assessed from the perspective of productivity, profitability, sales price, production cost, and added value (Gu \& Yan, Talavera et al., 2017; Snieska, 2015; Ajitabh \& Momaya, 2004). 
The concept of productivity is frequently used in the literature as a synonym for competitiveness and perceived as an indicator that promotes competitiveness on the long run (Ajitabh \& Momaya, 2004). The productivity of a company is considered to be a support for competitiveness (Delbari et al., 2016; Jackson, 1999; Bernolak, 1997). Assessing the impact of productivity on competitiveness is important as studies generally indicate a slowdown in productivity growth between 1950 and 2013 (OECD 2015). The Irish National Competitiveness Council (INCC) uses company productivity as a direct measurement tool for competitiveness and it also explicitly mentions the key role of cost in corporate competitiveness (INCC, 2016).

The labour cost has the highest impact on competitiveness from all cost categories (KPMG, 2016). The study reveals a level of labour costs for the services sector of 58-61 \%, while for the manufacturing sector it drops to 28$40 \%$ from the total of production-incurred costs.

The added value per employee in business services in England is considered to have a significant impact in terms of increased competitiveness and financial performance (O'Farrell et al., 1992).

The literature hypothesis assumes that companies are becoming more competitive with a majority shareholder (Bodnaruk et al., 2016). The evolution of competitiveness for companies controlled by foreign shareholders is explained in Germany through trading results, the export share of local production and the public subventions which support the science base of technological activities (Grupp, 1997). In Ireland there is a large gap in productivity between foreign and domestic owned companies (Ketels, 2016). The shareholding structure is able to condition the performance level. This aspect is studied in the literature as a comparison between the perspective of foreign owned companies, which are generally more efficient, and domestic-owned companies (Schwab \& Sala-i-Martin, 2011; Bloom \& Van Reenen, 2010; Aydin et al., 2007; Douma et al., 2006, Barbosa \& Louri, 2005; Chong, 2005; Narula, 2002).

\section{The Methodology and Model}

There are a number of European organizations that collect data regarding the competitiveness of companies from various perspectives. This study is based on data provided by Eurostat. The data included in this study covers 6 years in the 2008-2013 timeframe. This covers the period after the economic and financial crisis. When this study was conducted, the latest data published by Eurostat included in the research refer to the year 2013 (considering that final data are generally published two years after the end of the reference year, according to Eurostat).

The companies included in the study provide professional services of audit, accounting, bookkeeping and tax consultancy. The values of the indicators set for measuring competitiveness are taken into account for the general average value achieved in the European Union , Romania and France . The category Best EU Country consists of the EU countries with the best values for each key success factor selected for assessing competitiveness. Practically, this category designates the optimal/ ideal level of competitiveness in the EU for the companies in the audit, accounting, bookkeeping, and tax consultancy fields.

To test the hypotheses in the literature related to higher competitiveness within foreign owned companies (Ketels, 2016; Schwab \& Sala-i-Martin, 2011; Bloom \& Van Reenen, 2010; Aydin et al., 2007; Douma et al., 2006; Barbosa \& Louri, 2005; Chong, 2005; Narula, 2002) the impact of corporate governance from the perspective of foreign shareholding has also been studied for the Romanian foreign owned companies $\left(C_{5}\right)$ and the French foreign owned companies $\left(C_{6}\right)$. The values cover the last six years, for which the data were available when the study was conducted (time period 2008-2013).

To measure the competitiveness of companies in this timeframe in terms of sophisticated business practices, there were selected the following indicators related to the two aspects that characterize the sophisticated business practices according to the literature: competitiveness through assets and processes on the one hand, and competitiveness through performance on the other hand.

For the first approach, in order to measure the impact of assets and processes on competitiveness (Marin et al., 2017; Bagur-Femenias et al., 2015; Zhang, 2014; Shee, 2002; Ross et al., 1996; Skilbeck \& Cruickshank, 1997) the level of investment rate achieved by the corporate governance of the entities included in the study was selected. The second perspective refers to measuring the impact of performance on company competitiveness through profitability, productivity, cost and added value (Delbari et al., 2016; Snieska, 2015; Ajitabh \& Momaya, 2004; Jackson, 1999; Bernolak, 1997; O'Farrell et al., 1992). In this context, the following indicators have been taken into consideration as shown in Table 1: investment rate, gross operating rate, turnover per person employed, share of personal cost in production and added value at factor cost in production value.

Table 1

Key Success Factors and the Values During 2008-2013 in Order to Achieve the Competitiveness Ranking

\begin{tabular}{|c|c|c|c|c|c|c|c|}
\hline Key success factor & $\begin{array}{c}\text { Type } \\
\text { (Direct/ } \\
\text { Indirect) }\end{array}$ & EU average & $\begin{array}{c}\text { Romanian } \\
\text { average- } \\
\text { general }\end{array}$ & $\begin{array}{c}\text { France } \\
\text { average - } \\
\text { general }\end{array}$ & $\begin{array}{l}\text { Best EU } \\
\text { Country }\end{array}$ & \begin{tabular}{|c|}
$\begin{array}{c}\text { Romanian } \\
\text { average- } \\
\text { foreign } \\
\text { owned }\end{array}$ \\
\end{tabular} & $\begin{array}{c}\text { France } \\
\text { average - } \\
\text { foreign } \\
\text { owned }\end{array}$ \\
\hline Investment rate $(\%)$ & $\mathrm{D}$ & 4.25 & 10.85 & 2.26 & 19.12 & 5.22 & 1.90 \\
\hline Gross Operating Rate (\%) & $\mathrm{D}$ & 26.74 & 25.85 & 10.77 & 42.93 & 13.78 & 9.88 \\
\hline Turnover per person employed (thousands euro/head) & $\mathrm{D}$ & 68.24 & 20.57 & 102.70 & 148.57 & 64.90 & 414.10 \\
\hline Share of personnel costs in production (\%) & I & 41.24 & 26.10 & 52.86 & 20.58 & 40.27 & 26.05 \\
\hline Added value at factor cost in production value (millions Euro) & $\mathrm{D}$ & 68.26 & 51.37 & 63.60 & 81.42 & 59.90 & 246.68 \\
\hline
\end{tabular}

Source: Processing performed by the author using data provided by Eurostat 
To establish a competitiveness hierarchy of these six categories of audited entities, we considered the competitiveness analysis methods enshrined in the literature.

The weighted geometric mean of the key success factors for ranking the six categories of companies is the first competitiveness analysis method used in this study, also called the synthetic indicator method (Achim, 2009). The geometric mean method has also been used to create the composite the World Knowledge Competitiveness Index (WKCI) by using a quantitative analytical technique (Huggins et al., 2005) called Data Envelopment Analysis (DEA). The synthetic indicator is calculated as follows:

$$
\operatorname{Isg}(k)=\sqrt[n]{\frac{\prod_{i=1}^{m} I i(k)}{\prod_{j=1}^{p} I j(k)}}
$$

Where

- The global synthetic indicator of the category of companies $k$

$I i(k)$ - The direct indicator key success factor $i$ of the category of companies $k$
- The indirect indicator key success factor of the category of companies $k$

$$
\begin{gathered}
m \text { - The number of direct key success factors } \\
p \text { - The number of indirect key success factors }
\end{gathered}
$$

The highest value shall appoint the most competitive category of companies.

The second method used for the competitiveness analysis is the competitive profile matrix (CPM). This method involves assessing the companies' competitiveness by using a matrix in which the lines (i) represent the key success factors and the columns (j) represent the ranks of the companies in the classification according to a particular key success factor (Fleisher \& Bensoussan, 2015; Capps \& Glissmeyer, 2012; Gordon, 1989). In order to build the matrix, each rank from the hierarchy received a score in descending order (Achim, 2009) calculated as follows:

$$
I j \square\left\{\frac{1}{2}, \frac{1}{2^{2}}, \frac{1}{2^{3}}, \ldots, \frac{1}{2^{m}}\right\}, j=\overline{1, m}
$$

Where:

$m$ - The number of companies in the study

Building a competitive profile matrix implies the following procedures as presented in Figure 1:

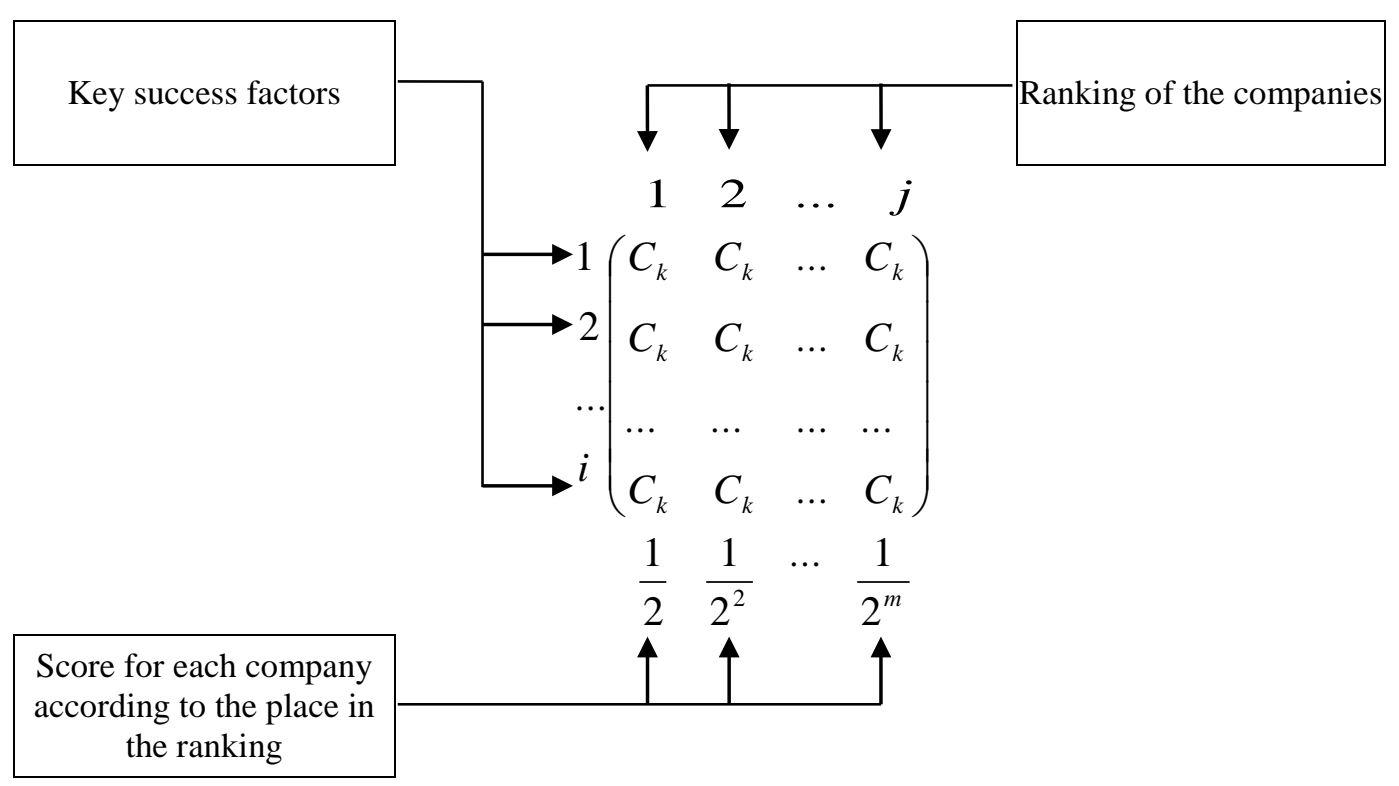

Figure1.The Competitive Profile Matrix

The score accumulated by each company is calculated as the weighted sum of the number of occurrences of a certain $\operatorname{rank}(j)$, for each of the companies included in the study $(k)$ and the score given to that particular place in the ranking $(I j)$, as follows:

$$
M s(k)=\sum_{j=1}^{m} \operatorname{Ijx}\left(\sum_{i=1}^{n} n i j(k)\right)
$$

Where:

$M s(k)$ - The calculated value which incorporates the competitiveness of the category $(k)$ 
Ij - The accumulated score pre-established for each $\operatorname{rank}(j)$

$n i j(k)$ - The score corresponding to each company $(k)$, for each rank $(j)$, based on each success factor $(i)$

The distance method, which is the third competitiveness analysis method used, is also applied to other key success factors which measure competitiveness (World Bank Group, 2016). This is the case with the World Bank's most popular knowledge product targeting laws and regulations that impact the operational costs across countries.

This method involves measuring the distance for each category of companies, for each key success factor, up to the value considered optimal for each key success factor. For the direct key success factors, the optimal value from this study's perspective will be considered the highest and for the indirect key success factors, the optimal value will be the lowest. The companies with the lowest value of this indicator may be considered the most competitive. The measurement of distances is made as follows:

$$
D e(k)=\sqrt{\sum_{i=1}^{n}\left(1-\frac{I i(k)}{I i(e)}\right)^{2}}
$$

Where:

$D e(k)$ - The distance between each category of companies and the benchmark category

Ii $(k)$ - The indicator of the direct or indirect key success factor $(i)$ of the category of companies $(k)$

Ii $(e)$ - The indicator key success factor $(i)$ of the category of companies considered as benchmark (with the optimal value for that particular key success factor)
To get a full picture of the competitiveness we used the aggregation process, method known in the literature for synthesizing the conclusions of the competitiveness analysis (World Bank Group, 2016; Djankov et al., 2005). For aggregation, we used the final scores method (Achim, 2009). Applying it to the six categories of companies is to sum up the values achieved through the first three methods in order to establish a final competitiveness hierarchy. This method is based on granting each rank a differential score and summing them up. The final ranking will be determined according to the descending order of scores, as follows:

$$
P k=\sum_{j=1}^{m} P j(k)
$$

Where,

$P(k)$ - The total score accumulated by each of the four categories of companies

$P j(k)$ - The score corresponding to each rank $(j)$ of each category $(k)$ (the first place from the ranking receives the highest number of points)

\section{Results and Discussions}

Following the data processing for the 2008-2013 timeframe for the six categories of companies operating at European level in the fields of professional audit services, accounting, bookkeeping and tax consultancy, starting from the first three above mentioned competitiveness analysis methods, we obtained the information shown in Table 2. This table presents the competitiveness ranking for the six categories of companies, separately for each method applied for evaluation.

Table 2

The Competitiveness of the Companies form the Fields of Professional Audit Services, Accounting, Bookkeeping and Tax

\begin{tabular}{|c|c|c|c|c|c|c|}
\hline \multirow{3}{*}{ Categories of analyzed companies } & \multicolumn{6}{|c|}{ Competitiveness analysis methods applied } \\
\hline & \multicolumn{2}{|c|}{$\begin{array}{l}\text { Synthetic } \\
\text { Indicator }\end{array}$} & \multicolumn{2}{|c|}{$\begin{array}{c}\text { Competitive Profile } \\
\text { Matrix (CPM). }\end{array}$} & \multicolumn{2}{|c|}{ Distance } \\
\hline & Amount & Top & Amount & Top & Amount & Top \\
\hline UE average for companies & 6.63 & III & 0.53 & IV & 1.72 & IV \\
\hline Romanian companies average- general & 6.47 & IV & 0.59 & III & 1.39 & III \\
\hline French companies average - general & 4.96 & VI & 0.27 & VI & 2.22 & VI \\
\hline Best EU company level & 13.70 & $\mathrm{I}$ & 2.00 & $\mathrm{I}$ & 0.93 & $\mathrm{I}$ \\
\hline Romanian companies average - foreign owned & 5.87 & $\mathrm{~V}$ & 0.31 & $\mathrm{~V}$ & 1.79 & $\mathrm{~V}$ \\
\hline French companies average - foreign owned & 9.41 & II & 1.28 & II & 1.38 & II \\
\hline
\end{tabular}
Consultancy after Applying the First three Competitiveness Analysis Methods

Source: Processing performed by author 
Each of the three competitiveness analysis methods applied has almost the same results regarding the final competitiveness ranking. The exceptions would be the "UE average for companies" and the „Romanian companies average-general” where there is an alternation for the places three and four in the ranking. The relative similarity between rankings provides representativeness and relevance to the results.

The final scores method ensures the aggregation of the results of previously applied methods and the achievement of a centralized situation regarding the competitiveness of the six categories of companies. By taking into consideration the scores accumulated by each category of entities according to the place in the ranking (from 6 points for the $1^{\text {st }}$ place to 1 point for the $6^{\text {th }}$ place) and their accumulation based on the above mentioned method, we obtained in Table 3 a final statement for the 2008-2013 timeframe of the competitiveness analysis within companies operating at European level in the fields of professional audit services, accounting, bookkeeping and tax consultancy. Therefore, a higher number of accumulated points according to the aggregate situation ensure a better final place, at a higher level in the final competitiveness hierarchy

Competitiveness of the Companies form the Fields of Professional Audit Services, Accounting, Bookkeeping and tax Consultancy after Aggregating the Results Obtained from the Competitiveness Analysis

\begin{tabular}{|c|c|c|c|c|c|c|c|c|c|}
\hline \multirow{3}{*}{ Rank } & \multirow{3}{*}{ Score } & \multicolumn{6}{|c|}{ Individual competitiveness methods } & \multicolumn{2}{|c|}{$\begin{array}{c}\text { The competitiveness analysis of } \\
\text { aggregation results }\end{array}$} \\
\hline & & \multicolumn{2}{|c|}{$\begin{array}{l}\text { Synthetic } \\
\text { Indicator }\end{array}$} & \multicolumn{2}{|c|}{$\begin{array}{c}\text { Competitive Profile Matrix } \\
\text { (CPM). }\end{array}$} & \multicolumn{2}{|c|}{ Distance } & \multirow[t]{2}{*}{ Score } & \multirow[t]{2}{*}{ Final Ranking } \\
\hline & & Ranking & Score & Ranking & Score & Ranking & Score & & \\
\hline I & 6 & & 6 & & 6 & & 6 & $18 p$ & \\
\hline II & 5 & & 5 & & 5 & & 5 & $15 p$ & \\
\hline III & 4 & & 4 & & 4 & & 4 & $11 \mathrm{p}$ & \\
\hline IV & 3 & & 3 & & 3 & & 3 & 10p & \\
\hline V & 2 & & 2 & & 2 & & 2 & $6 \mathrm{p}$ & \\
\hline VI & 1 & & 1 & & 1 & & 1 & $3 p$ & \\
\hline
\end{tabular}

Source: Processing performed by author

The best score and the first rank in the competitiveness analysis is achieved by the category "Best EU Country" $\left(C_{4}\right)$ because it consists of the EU countries with the best average values in the 2008-2013 timeframe for each of the five key success factors for assessing competitiveness. For the Gross Operating Rate (GOR) the best level is achieved by the Italian companies, for the turnover per person employed by Luxembourg, for the share of personnel costs in production and investment rate by Belgium and for the added value at factor cost in production value by the companies from Cyprus. The results of the study indicate that the French companies with foreign control $\left(C_{6}\right)$ have a level of competitiveness (83 \%) very close to the Best EU company level $\left(C_{4}\right)$, which is also the optimal level, the benchmark for the study. Their competitiveness is superior to the Romanian companies, irrespective of the shareholder structure, foreign owned or not, as well as to the EU average for companies $\left(C_{1}\right)$. The level of competitiveness within the Romanian companies $\left(C_{2}\right)$ is above the level of the average competitiveness registered at the EU level.

The hypothesis from the literature according to which the foreign owned companies are generally more competitive (Ketels, 2016; Schwab \& Sala-i-Martin, 2011;
Bloom \& Van Reenen, 2010; Aydin et al., 2007; Douma et al., 2006; Barbosa \& Louri, 2005; Chong, 2005; Narula, 2002) is confirmed in the case of French companies average with foreign control $\left(C_{6}\right)$ for the companies operating in the fields of audit, accounting and tax consultancy. According to the data provided in Table 4 the accumulated score is 15 points (83 \% from the optimal level/ benchmark) compared to 3 points accumulated by the French companies average - general $\left(C_{3}\right)$ in the final ranking of the competitiveness analysis $(17 \%$ of the optimal level/ benchmark).The competitiveness of French companies with foreign control is very close to the optimal level recorded by the most competitive companies in Europe. The same hypothesis is not confirmed in the case of the Romanian companies with foreign control $\left(C_{5}\right)$, which have a lower competitiveness (6 points, $33 \%$ from the benchmark) than the average registered within the Romanian companies (11 points, $61 \%$ from the level considered benchmark) $\left(C_{2}\right)$. 
Summary of the Competitiveness Analysis Results

\begin{tabular}{|c|c|c|c|}
\hline \multirow{2}{*}{ Categories of analyzed companies } & \multicolumn{3}{|c|}{ Results after aggregation } \\
\hline & Score & Ranking & Percentage \\
\hline Best EU company level & $18 p$ & & $100 \%$ \\
\hline French companies average - foreign owned & $15 p$ & & $83 \%$ \\
\hline Romanian companies average - general & $11 \mathrm{p}$ & & $61 \%$ \\
\hline UE average for companies & $10 \mathrm{p}$ & & $56 \%$ \\
\hline Romanian companies average - foreign owned & $6 p$ & & $33 \%$ \\
\hline French companies average - general & $3 p$ & & $17 \%$ \\
\hline
\end{tabular}

Source: Processing performed by author

\section{Conclusions}

The competitiveness of the French foreign controlled companies from the accounting business field is supported by the achievement of the best average level of turnover per person employed (414.10 thousands euro per head) and the best average level of added value at factor cost in production value (246.68 million euro) based on corporate governance decisions in the 2008-2013 timeframe. These companies are less competitive in terms of investment rate (1.90\%), being below the European average for the accounting business field (4.25\%). In order to support competitiveness through performance, the corporate governance of these companies should make decisions on increasing the rate of investment. On the other hand, competitiveness is supported by a low level (26.05\%) of labour costs (26.05\%), which is the most important component of competitiveness (KPMG, 2016). This is below the EU average level (41.24 \%) and far below the average level mentioned in the literature for the services sector as a whole (58-61 \%) (KPMG, 2016). The corporate governance of this category of companies supports this high level of competitiveness through productivity and added value (Gu \& Yan; Delbari et al., 2016; Ajitabh and Momaya, 2004). The hypothesis that investments support competitiveness is invalidated in this case (Marin et al., 2017; Bagur-Femenias et al., 2015; Zhang, 2014; Shee, 2002; Ross et al, 1996), because the most competitive companies have the lowest average investment rate (1.9 $\%)$.

The Romanian companies from the accounting business field achieve an overall level of competitiveness slightly above the European level. Competitiveness is supported by the corporate governance decisions to diminish the share of personnel cost in production (26.10 \%) similar to the French foreign owned companies (26.05 $\%)$, but contrary to the Romanian foreign owned companies, where the indicator is higher (40.27\%). The management of the Romanian companies, taken as a whole, adopts a different policy of investment growth (10.85\%) than the French foreign owned companies (1.9 $\%$ ) in terms of a lower added value (51.37 million euro), but close to the EU average (68.26 million euro). On the other hand, the level of Gross Operating Rate is much higher $(25.85 \%)$ than that of the French foreign owned companies (9.88\%).This approach can lead to medium and long term increase in outputs and, implicitly, in competitiveness for these companies.

For the Romanian companies operating in the financial-accounting business field, corporate governance opts to increase competitiveness to reduce personnel costs (KPMG, 2016) similar to the French foreign controlled companies. In addition, competitiveness is supported by other decisions related to increasing profitability (Talavera et al., 2017; Snieska, 2015) and investments (Marin et al., 2017; Bagur-Femenias et al., 2015; Zhang, 2014; Shee, 2002; Ross et al, 1996). The hypothesis that added value supports competitiveness is not confirmed in this case $(\mathrm{Gu}$ \& Yan; Delbari et al., 2016; Ajitabh and Momaya, 2004) because the lowest value was registered for this indicator.

Therefore, the foreign owned companies operating in the accounting-business field are increasing their competitiveness through corporate governance decisions on reducing labour cost, increasing productivity and added value. They invest far less than companies with local ownership, and corporate governance prefers other options for increasing competitiveness. Companies that are not foreign owned, increase competitiveness by reducing labour costs, increasing profitability and investing. National companies invest more than foreign owned companies. Reducing labour costs is an option adopted by corporate governance regardless the shareholder structure.

The results of the study contribute to the literature by providing a method to assess the diversity of corporate governance options for increasing competitiveness, starting from data submitted through annual reporting, highlighting a difference between options for foreign controlled companies, and emphasizing issues that can be improved in order to increase competitiveness.

This study presents perspectives of further research by considering multiple variables with impact on competitiveness: the level of $\mathrm{R} \& \mathrm{D}$ expenditures, the interest of management in staff training, staff stability, the tenure of the companies, and the existence of clusters.

One of the limitations of this study is the availability of data processed within a short period of time to allow the publication of the results of the operative research. The data provided by the companies that operate in the accounting business field and provide professional services of audit, accounting, bookkeeping and tax consultancy are also transmitted with some delay. The results obtained and the conclusions drawn are specific to the services sector in 
general and to the audit and accounting services in particular. It might be interesting to check the results of the study for an extended period of time.

The research results capture the competitiveness in the period after the economic and financial crisis of the companies that provide professional audit services in the fields of accounting, bookkeeping and tax consultancy. This highlights the companies' ability to become competitive again, to create value for shareholders and also the options which corporate governance adopts in this regard.

\section{Acknowledgements}

This work was supported by „Babes-Bolyai” University Romania, through the Funding contract for the implementation of grants for young researchers; project number 31781/23.03.2016 „Corporate governance particularities and their impact on financial statements”.

\section{References}

Achim, M.V.(2009). Analiza economico-financiara. Bucuresti: Publishing Risoprint.

Ajitabh, A., \& Momaya, K.S. (2004). Competitiveness of firms: review of theory, frameworks and models. Singapore management review, 26(2), 45-61.

Aydin, N., Sayim, M., \&Yalama, A. (2007). Foreign ownership and firm performance: Evidence from Turkey. International Research Journal of Finance and Economics, 11,103-111.

Bagur-Femenias, L., Perramon, J., \& Amat, O. (2015). Impact of quality and environmental investment on business competitiveness and profitability in small service business: The case of travel agencies. Total Quality Management \& Business Excellence, 26(7-8), 840-853. https://doi.org/10.1080/14783363.2014.895523

Bambenger, I. (1989). Developing competitive advantage in small and medium-size firms. Long Range Planning, 22(5), 80-88. https://doi.org/10.1016/0024-6301(89)90172-6

Barbosa, N., \& Louri, H. (2005). Corporate performance: does ownership matter? A comparison of foreign-and domesticowned firms in Greece and Portugal. Review of Industrial Organization, 27(1), $73-102$. https://doi.org/10.1007/s11151-005-4920-y

Bernolak, I. (1997). Effective measurement and successful elements of company productivity: The basis of competitiveness and world prosperity. International Journal of Production Economics, 52(1), $203-213$. https://doi.org/10.1016/S0925-5273(97)00026-1

Bloom, N., \& Van Reenen, J. (2010). Why do management practices differ across firms and countries? The Journal of Economic Perspectives, 24(1), 203-224. https://doi.org/10.1257/jep.24.1.203

Bodnaruk, A., O'Brien, W., \& Simonov, A. (2016). Captive finance and firm's competitiveness. Journal of Corporate Finance, 37, 210-228. https://doi.org/10.1016/j.jcorpfin.2015.12.018

Boland, P. (2014). The relationship between spatial planning and economic competitiveness: the 'path to economic nirvana'or a 'dangerous obsession'? Environment and Planning A, 46(4), 770-787. https://doi.org/10.1068/a4687

Capps III, C. J., \& Glissmeyer, M. D. (2012). Extending the competitive profile matrix using internal factor evaluation and external factor evaluation matrix concepts. Journal of Applied Business Research, 28(5), 1059-1062. https://doi.org/10.19030/jabr.v28i5.7245

Cetindamar, D., \& Kilitcioglu, H. (2013). Measuring the competitiveness of a firm for an award system. Competitiveness Review: An International Business Journal, 23(1), 7-22. https://doi.org/10.1108/10595421311296597

Chaston, I., \& Mangles, T. (1997). Core capabilities as predictors of growth potential in small manufacturing firms. Journal of Small Business Management, 35(1), 47-57.

Chong, H. W. W. X. G. (2005). Positive Analysis on Factors that Have Impact on Competitiveness of China's Service Trade. International Trade Journal, 2, 11.

Chuang, S. P., \& Huang, S. J. (2016). The effect of environmental corporate social responsibility on environmental performance and business competitiveness: The mediation of green information technology capital. Journal of Business Ethics, April, not assigned to an issue, 1-19. https://doi.org/10.1007/s10551-016-3167-X

D'Cruz, J., \& Rugman, A. (1992). New concepts for Canadian competitiveness, Kodak, Canada, 1-60.

Deaconu, A., \& Cuzdriorean, D. D. (2016). Accounting and the state in post-communist Romania. African Journal of Accounting, Auditing and Finance, 5(1), 59-93. https://doi.org/10.1504/AJAAF.2016.077600

Delbari, S. A., Ng, S. I., Aziz, Y. A., \& Ho, J. A. (2016). An investigation of key competitiveness indicators and drivers of 
full-service airlines using Delphi and AHP techniques. Journal of Air Transport Management, 52, $23-34$. https://doi.org/10.1016/j.jairtraman.2015.12.004

Delgado, M., Ketels, C., Porter, M. E., \&Stern, S. (2012). The determinants of national competitiveness. National Bureau of Economic Research, $18249 . \quad$ Available from internet: http://www.clustermapping.us/sites/default/files/files/resource/The_Determinants_of_National_Competitiveness.pdf. https://doi.org/10.3386/w18249

Diaz-Chao, A., Sainz-Gonzalez, J., \& Torrent-Sellens, J. (2016). The competitiveness of small network-firm: A practical tool. Journal of Business Research, 69(5), 1769-1774. https://doi.org/10.1016/j.jbusres.2015.10.053

Djankov, S., Manraj, D., McLiesh, C., \& Ramalho, R. (2005). Doing Business Indicators: Why Aggregate, and How to Do It. Washington, DC: World Bank.

Douma, S., George, R., \& Kabir, R. (2006). Foreign and domestic ownership, business groups, and firm performance: Evidence from a large emerging market. Strategic Management Journal, 27(7), $637-657$. https://doi.org/10.1002/smj.535

Fleisher, C. S., \& Bensoussan, B. E. (2015). Business and competitive analysis: effective application of new and classic methods. FT Press.

Gordon, I. (1989). Beat the Competition. How to Use Competitive Intelligence to Develop Winning Business Strategies. Oxford: Basil Blackwell Publishers.

Johnson, H. T. (1994) Relevance regained: total quality management and the role of management accounting. Critical Perspectives on Accounting, 5(3), 259-267. https://doi.org/10.1006/cpac.1994.1015

Grosanu, A., Bota-Avram, C., Rachisan, P. R., Vesselinov, R., \& Tiron-Tudor, A. (2015). The influence of country-level governance on business environment and entrepreneurship: A global perspective. Amfiteatru Economic, 17(38), 6075.

Grupp, H. (1997). The links between competitiveness, firms' innovative activities and public R\&D support in Germany: an empirical analysis. Technology Analysis \& Strategic Management, 9(1), $19-34$. https://doi.org/10.1080/09537329708524267

Gu, W., \& Yan, B. (2017). Productivity Growth and International Competitiveness. Review of Income and Wealth, 63(s1), 113-133. https://doi.org/10.1111/roiw.12254

Guerrieri, P., \& Meliciani, V. (2005). Technology and international competitiveness: the interdependence between manufacturing and producer services. Structural Change and Economic Dynamics, 16(4),489-502. https://doi.org/10.1016/j.strueco.2005.02.002

Hardwick, P., \& Dou, W. (1998). The competitiveness of EU insurance industries. Service Industries Journal, 18(1), 3953. https://doi.org/10.1080/02642069800000003

Huggins, R., Izushi, H., \& Davies, W. (2005). World knowledge competitiveness index 2005.Available from internet: http://eprints.aston.ac.uk/18412/1/World_knowledge_competitiveness_index_2005.pdf

Husain, Z., Dayan, M., \& Di Benedetto, C. A. (2016). The impact of networking on competitiveness via organizational learning, employee innovativeness, and innovation process: A mediation model. Journal of Engineering and Technology Management, 40, 15-28. https://doi.org/10.1016/j.jengtecman.2016.03.001

Kharub, M., Kharub, M., Sharma, R., \& Sharma, R. (2017). Comparative analyses of competitive advantage using Porter diamond model (the case of MSMEs in Himachal Pradesh). Competitiveness Review: An International Business Journal, 27(2), 132-160. https://doi.org/10.1108/CR-02-2016-0007

Jackson, M. (1999). Productivity-an overall measure of competitiveness. Proceedings of the Second International Workshop, Intelligent Manufacturing Systems. Available from internet: http://mdh.divaportal.org/smash/record.jsf?pid=diva2\%3A301769\&dswid=-4943

Ketels, C. (2016). An Analysis Conducted for the Irish National Competitiveness Council. Review of Competitiveness Frameworks

Marin, L., Martin, P. J., \& Rubio, A. (2017). Doing Good and Different! The Mediation Effect of Innovation and Investment on the Influence of CSR on Competitiveness. Corporate Social Responsibility and Environmental Management, 24(2), 159-171. https://doi.org/10.1002/csr.1412

Mendola, D., \& Volo, S. (2017). Building composite indicators in tourism studies: Measurements and applications in tourism destination competitiveness. Tourism $\quad$ Management, $591-553$. https://doi.org/10.1016/j.tourman.2016.08.011 
Narula, R. (2002). Multinational investment and economic structure: Globalisation and competitiveness. London and New York: Routledge.

O'Farrell, P. N., Hitchens, D. M. W. N., \& Moffat, L. A. R. (1992). The competitiveness of business service firms: a matched comparison between Scotland and the South East of England. Regional Studies, 26(6), 519-533. https://doi.org/10.1080/00343409212331347171

Patlan-Perez, J., \&De Lara, P. V. (2012). Competitive potential of small business to attract human talent. African Journal of Business Management, 6 (38), 10273-10283.

Perez-Moreno, S., Rodriguez, B., \& Luque, M. (2016). Assessing global competitiveness under multi-criteria perspective. Economic Modelling, 53, 398-408. https://doi.org/10.1016/j.econmod.2015.10.030

Porter, M. E. (2011). Competitive advantage of nations: creating and sustaining superior performance. Simon and Schuster. New York: The Free Press.

Porter, M. E. (1990). The competitive advantage of nations. Harvard business review, 68(2), $73-93$. https://doi.org/10.1007/978-1-349-11336-1

Porter, M. E., Rivkin, J. W., \& Kanter, R. M. (2013). Competitiveness at a Crossroads, Boston: Harvard Business School.

Rachisan, P. R., Boța-Avram, C., \& Grosanu, A. (2017). Investor protection and country-level governance: cross-country empirical panel data evidence. Economic research-Ekonomska istrazivanja, 30(1), $806-817$. https://doi.org/10.1080/1331677X.2017.1311226

Ross, J. W., Beath, C. M., \& Goodhue, D. L. (1996). Develop long-term competitiveness through IT assets. MIT Sloan Management Review, 38(1), 31-42.

Schwab, K., \& Sala-i-Martin, X. (2011). The global competitiveness report 2011-2012.Geneva: World Economic Forum. Available from internet: http://citeseerx.ist.psu.edu/viewdoc/download?doi=10.1.1.227.2921\&rep=rep1\&type=pdf.

Shee, H. (2002). Competitiveness through technological excellence: A case of Indian software industry. Doctoral Research, Dept of Management Studies, IIT Delhi India.

Skilbeck, J. N., \& Cruickshank, C. M. (1997). A framework for evaluating technology management process. Proceedings. of Portland International conference on management of engineering and technology, Portland, $138-142$. https://doi.org/10.1109/PICMET.1997.653296

Smith, S. (1995). World-class competitiveness. Managing Service Quality: An International Journal, 5(5), 36-42. https://doi.org/10.1108/09604529510100387

Snieska, V. (2015). Research into international competitiveness in 2000-2008. Inzinerine Ekonomika-Engineering Economics, 59(4).

Talavera, D. L., Perez-Higueras, P., Almonacid, F., \& Fernandez, E. F. (2017). A worldwide assessment of economic feasibility of HCPV power plants: Profitability and competitiveness. Energy, 119, $408-424$. https://doi.org/10.1016/j.energy.2016.12.093

Wayne Pace R., \& Stephan, E. G. (1996). Paradigms of competitiveness. Competitiveness Review: An International Business Journal, 6(1), 8-13. https://doi.org/10.1108/eb046325

Westerlund, M., Isabelle, D. A., Rajala, R., \& Leminen, S. (2017). Networks, business models, and competitiveness in small Finnish firms. International Journal of Business and Globalisation, 18(1), 9-26. https://doi.org/10.1504/IJBG.2017.081029

Wu, L., \& Chiu, M. L. (2015). Organizational applications of IT innovation and firm's competitive performance: A resource-based view and the innovation diffusion approach. Journal of Engineering and Technology Management, 35, 25-44. https://doi.org/10.1016/j.jengtecman.2014.09.002

Zhang, K. H. (2014). How does foreign direct investment affect industrial competitiveness? Evidence from China. China Economic Review, 30, 530-539. https://doi.org/10.1016/j.chieco.2013.08.003

*** World Bank Group, Doing business 2016. Measuring regulatory quality and efficiency, Comparing Business Regulation for domestic firms in 189 economies, A world Bank flagship report, 13th edition. Available from internet http://www.doingbusiness.org/ /media/GIAWB/Doing\%20Business/Documents/Annual-Reports/English/DB16Full-Report.pdf in February 20th 2016.

The article has been reviewed.

Received in December, 2016; accepted in June, 2018. 